\title{
Trade Credit Contracts, Theories and their Applications: A Synthesis of the Literature
}

\author{
Stanley Kojo Dary \\ Department of Economics and Entrepreneurship Development, \\ University for Development Studies, Wa Campus, Ghana. \\ Email:sdary@uds.edu.gh \\ Harvey S. James Jr. \\ Division of Applied Social Sciences, \\ University of Missouri-Columbia, USA \\ Email: Hjames@missouri.edu \\ DOI//http://dx.doi.org/10.4314/gjds.v17i1.4
}

\begin{abstract}
The paper studies theories relating to trade credit contracts as well as their applications and limitations, via review and synthesis of the trade credit literature. Using keywords and search phrases, the literature was identified from key economics, business and finance domains. Trade credit contracts are not complex, this can be explained by factors such as shortness of credit period, frequent transactions, proximity and interaction between trading parties, and effective informal enforcement mechanisms. In contrast to the longstanding conception that trade credit is more expensive than bank credit, trade credit is often cheaper than bank credit, hence its high incidence and level of use across countries. The high use of trade credit should warrant some policy attention, particularly trade credit regulation. Theories explaining trade credit are highly interconnected; most of them have received considerable empirical support in both developed and developing countries. The interconnected nature of the trade credit theories should inform methodological approaches to their empirical testing and present an opportunity for comprehensive theory development in the field.
\end{abstract}

Keywords: Trade Credit, Trade Credit Contracts, Trade Credit Theories, Trade Credit Motives, Trade Credit Supply and Demand

JEL Classification: L66, G32, D22 


\section{INTRODUCTION}

The use of trade credit in interfirm trade is prominent in both developed and developing countries. Trade credit contracts are linked to purchases as well as sales of goods. The long history of trade credit as a common short-term financing practice among non-financial firms suggests that firms find value in it. A plethora of theories has emerged to explain why firms engage in trade credit activity as suppliers, receivers or both. Financial based theories were the first to emerge. Subsequently, non-financial based theories emerged including transaction cost and commercial theories. These theories have been subjected to empirical examinations (Petersen \& Rajan, 1997; García-Teruel \& Martínez-Solano, 2010; Long et al., 1993), albeit with mixed results. The focus and methodological approaches employed in the empirical literature are also varied.

Against this background, this paper seeks to: (i) examine the nature of trade credit contracts, (ii) examine trade credit theories, their applications and limitations, and (iii) provide empirical findings on trade credit theories. These objectives are addressed through a review and synthesis of the theoretical and empirical trade credit literature. The literature is drawn from IDEAS/RePEc, EconLit, Journal Storage (JSTOR), AgEcon Search, and Social Science Research Network (SSRN) using keywords and search phrases. Importantly, the objectives of this paper have not been adequately addressed in past reviews (Seifert et al., 2013; Bhattacharya, 2008). Seifert et al. (2013) undertook a review of the trade credit literature, focusing mainly on identifying opportunities for operations research. Their discussion of trade credit contracts and trade credit theories is limited. Bhattacharya (2008) also undertook a review of theories of trade credit, highlighting areas of application and limitations. However, that paper provided only a weak link between the theoretical and empirical literature. Also, trade credit contractual issues were not explored. This review paper is thus relevant for policy and practice at the firm, industry and national levels. By examining trade credit contracts and bringing the various theories under one umbrella and examining them collectively, the paper will serve as a comprehensive reference material for academics and practitioners in the field. Trade credit is an important financial development issue and unlike conventional credit, it has received limited attention by policymakers despite its widespread use. Therefore, this review should draw the attention of policymakers and national governments to trade credit and influence policy actions. It should also guide firms in making appropriate trade credit decisions, particularly credit terms, as givers and/or receivers of trade credit. Furthermore, it can shape future research as well as 
new theory development in the field. The rest of the paper is structured as follows: Part 1 provides an overview of trade credit while Part 2 reviews recent research on trade credit contracts, highlighting the elements. Part 3 presents and reviews trade credit theories highlighting their applications and limitations. The empirical evidence of the theories is also presented. Finally, Part 5 concludes the review.

\section{TRADE CREDIT OVERVIEW: TYPES AND EXTENT OF USAGE}

Trade credit takes different forms. When a firm sells goods to a buyer and no immediate cash payment is received, it is extending credit to the buyer (accounts receivable or supplier credit). When a firm buys goods from a supplier and payment is deferred to a later period, it is receiving credit from the supplier (accounts payable) (Emery, 1984; Ng et al., 1999; Carvalho \& Schiozer, 2015). Additionally, when a buyer pays for goods ahead of delivery, as an advanced or pre-payment, the buyer is extending credit to the supplier (Schwartz, 1974; Ferris, 1981; Ng et al., 1999); sometimes this is described in the literature as reverse trade credit (Daripa \& Nilsen, 2011; Mateut, 2014). However, the advanced payment type of trade credit is rare (Schwartz, 1974; Ferris, 1981; Ng et al., 1999; Cuevas et al., 1993). Unlike traditional credit, trade credit is a restricted type of financing, as credit is tied to sale or purchase of goods (Emery, 1984; Nadiri, 1969). Firms and banks lend goods and cash, respectively (Burkart \& Ellingsen, 2004). By standard accounting convention, trade credit appears under current assets as accounts receivable and current liabilities as accounts payable (Petersen \& Rajan, 1997). A firm can thus be a supplier and/or receiver of trade credit as illustrated in Figure 1. Many studies report that firms are net suppliers of trade credit - that is, they give more trade credit than they receive (Fafchamps et al., 1995; García-Teruel \& Martínez-Solano, 2010).

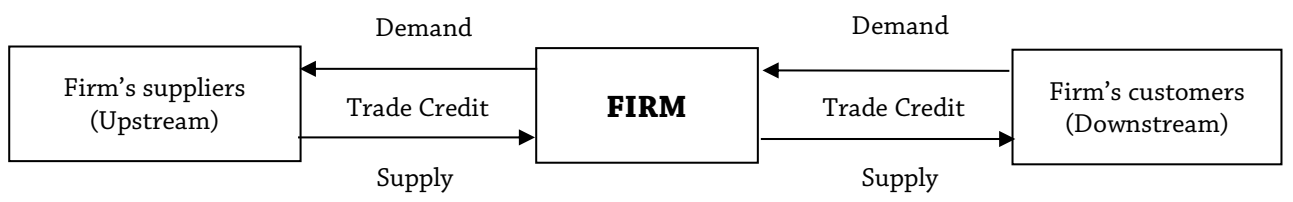

Figure 1: Trade Credit Demand and Supply Model

Source: Adopted from Petersen and Rajan (1997) 
With supplier credit, the supplier assumes greater portion of risk in a trade credit relationship. Conversely, the buyer assumes the greater portion of risk with advanced payment (Cuevas et al., 1993; Klapper et al., 2012). In general, firms can manage risks inherent in trade credit arrangements by shifting risks to third parties using factoring or credit insurance (Mian \& Smith, 1992). While credit from traditional financial intermediaries is subject to regulation, trade credit is largely unregulated (Marotta, 2005; Alarcón, 2011; Fabbri \& Klapper, 2008). Countries in Europe are taking steps to regulate trade credit periods and stem late payments due to their possible negative impact on the financial sector (Alarcón, 2011; Marotta, 2005).

Trade credit is widely used around the world. Klapper et al. (2012) reports that an estimated 90\% of global merchandise trade was financed by trade credit in 2007. According to Marotta (2005), Italy is leading the world in trade credit transactions, with almost all inter-firm trade occurring on trade credit terms. Ellingsen et al. (2016) notes that almost all inter-firm trade in Sweden involves trade credit. Elliehausen and Wolken (1993) reports that trade credit exists among 80\% of firms in the United Kingdom (UK). Among publicly listed agro-food firms in the United States (US), nearly all firms supply trade credit (Dary \& James, 2019). In France, Boissey and Gropp (2007) found almost every firm extends trade credit to customers and receives trade credit from suppliers. Carvalho and Schiozer (2015) report that $67.74 \%$ of total purchases among firms in Brazil is on credit basis while Vaidya (2011) reports accounts receivable and payable of $24 \%$ and $17 \%$ of total sales, respectively, in India. In Africa, Fafchamps et al. (1995) report $81 \%$ and $64 \%$ of total purchases and sales, respectively, by firms on credit basis in Zimbabwe. Kihanga et al. (2010) report accounts receivable constitute $67 \%$ of total sales among Tanzanian rice traders. In Ghana, Cuevas et al. (1993) report about 55.6\% and 66.75 of firms grant and receive trade credit, respectively. Dary and James (2018) report 55\% and $60 \%$ of agro-food firms in Africa receive and supply trade credit, respectively. The wide use of trade credit thus suggests that it may be a cheaper form of credit.

\section{TRADE CREDIT CONTRACTS}

Trade credit is a contractual relationship between two trading parties - a supplier and a customer. Following Klapper et al. (2012), a trading party (supplier) promises to deliver a quantity, $f$, at time $t_{1}$ to another party in exchange for a quantity, $k$, at time $t_{2}$. Depending on the direction of flow of credit, quantity $k$ and $f$ could each be money or a good. If trade credit is from a supplier to a buyer, $k$ will be a good and 
$f$ will be money. Conversely, if it is advance payment type of trade credit, $k$ will be money and $f$ will be a good. Though the terms of trade credit vary cross-sectionally and inter-temporally (Ng et al., 1999; Smith, 1987; Cuevas et al., 1993), most trade credit contracts are very simplified. In its simplest form, it is an invoice (see Figure $\mathrm{A}_{1}$ and $\mathrm{A} 2$ in Appendices). Trade credit contracts are not fully contractual arrangements (Cuñat \& Garcia-Appendini, 2012) or are incomplete contracts (Wilson \& Summers, 2002). They do not generally follow the standard structure of business contracts. However, the simplicity of trade credit contracts does not suggest they are suboptimal. Sometimes the optimal contract is an incomplete contract, since contracting is not costless and thus the choice of level of contract (in) completeness is an economic decision (Crocker \& Raynold, 1993). The economisation of transaction cost of writing contracts is essential as high transaction cost can erase the potential gains to parties in a transaction.

Several arguments can be advanced for the non-complex nature of trade credit contracts. Firstly, because trade credit contracts have shorter time periods within which contract performance should be completed, the level of uncertainty regarding contract performance should be low. As the level of uncertainty increases with time, shorter trade credit periods mean that firms may not need to invest time and resources drafting complex contracts with contingency clauses to cater for uncertainties. Secondly, moral hazard and opportunism that arise from information asymmetries between transacting parties may be low in trade credit scenarios (see Ng et al., 1999), making trade credit contracts more simplified. Trade credit is relationship-based lending; it is generally extended to parties with whom a supplier has a business relationship (Nadiri, 1969). Suppliers and buyers obtain information about each other as a by-product of their proximity and frequent interactions (Ng et al., 1999), enabling them to reduce adverse selection ex ante, which in turn should lead to reduced opportunism ex post. Thirdly, when trade credit transactions are frequent, it will be costly to write elaborate contracts each time. Finally, due to close proximity and repeated interactions between suppliers and customers, trade credit contracts may easily be enforceable, reducing the burden of writing complex contracts. The enforceability of contracts influences the behaviour of transacting parties from that of non-cooperation to cooperation, thus creating economic efficiency. Trade credit relationships can be likened to an infinitely repeated game, where continuous cooperation is necessary to obtain a Nash equilibrium (see Nash, 1951). The cooperation of transacting parties depends on the effectiveness of enforcement mechanisms that makes the costs of non-compliance higher than the benefits of non-compliance (Cuevas et al., 1993; Fafchamps et al., 1995; Klapper 
et al., 2012). There are formal and informal mechanisms for enforcing contracts. Dyer (1997) states that the use of informal mechanisms such as threat of refusal of future business, coercion or harassment, and threat of legal action is effective at controlling opportunism or moral hazard in relationships that have an indefinite time horizon (such as trade credit relationships). Even though parties in trade credit relationships are less likely to use the formal legal system for contract enforcement (Cuevas et al., 1993), the quality of the legal system is important for confidence in doing business.

\section{Elements of Trade Credit Contracts and Empirical Evidence}

There are variations in trade credit contract terms depending on the transactors, transaction, industry and location (Smith, 1987; Long et al., 1993; Cuevas et al., 1993). According to Wilson and Summers (2002), credit terms 'refer to the written or stated policies given to a customer with regards to the timing of payments, discounts for early settlements, the methods of payment, ownership of goods prior to payment, and interest or penalties for late payment' (p.320). A typical trade credit contract will contain the identifying information of the contracting parties (e.g., names, addresses), the date of transaction, goods involved in the exchange and their currency value, discounts (if any) and period of maturity (see Figure A1 and Figure A2). Some trade credit contracts also contain penalty for delayed payment such as charging fees on amount past due (see Figure A2). Trade credit terms (or policies) are of two types: net terms and two-part terms (Ng et al., 1999; Smith, 1987). The net terms indicate the amount that should be paid in full at a due date following a transaction. As an illustration, 'net 30 ' means pay $x$ amount by the $30^{\text {th }}$ day following the transaction. The two-part terms involve a stated discount if early payment is received before the due date. To illustrate, '2/10 net 30' implies the customer will receive a discount of $2 \%$ off $x$ amount if payment is made in 10 days; else the entire $x$ amount is due by the $30^{\text {th }}$ day following the transaction. Figure A1 and Figure A2 are sample contracts containing net terms and two-part terms, respectively.

\section{The Amount of Trade Credit}

Generally, the amount of trade credit is conditioned on the amount of goods purchased (Burkart \& Ellingsen, 2004). The liquidity of the goods involved also influences trade credit amounts. Goods with high degree of liquidity lead to smaller amounts of trade credit and vice versa. Trade credit is high in transactions between suppliers and international customers for quality verification purposes ( $\mathrm{Ng}$ et al., 
1999; Cuevas et al., 1993). When the goods involved in the exchange are highly specific, trade credit amounts are higher (Costello, 2013). Trade credit amounts are also higher in markets characterised by high competition than in monopolies (Fisman \& Raturi, 2004). Firms with large volumes of inventories may also offer more trade credit (Elliehausen \& Wolken, 1993). Long et al. (1993) found that larger trade credit amounts are associated with goods with long production time, implying high quality or complex products. Low-quality or highly perishable products are less likely to be sold on credit. For instance, food firms sell less on credit (Fafchamps et al., 1995; Cuevas et al., 1993).

The empirical evidence on the effect of firm size and amount of trade credit extended and received appear mixed. Large firms have been found to extend larger amount of trade credit (Costello, 2013; Lin \& Chou, 2015; Carvalho \& Schiozer, 2015; Petersen \& Rajan, 1997) and receive larger amount of trade credit (Lin \& Chou, 2015, García-Teruel \& Martínez-Solano, 2010; Ferrando \& Mulier, 2013; Fisman \& Raturi, 2004). Inverse relationships have also been found between firm size and amount of trade credit supplied (Long et al., 1993; Alarcón, 2011) and amount of trade credit received (Kihanga et al., 2010). In terms of firm age, older firms are found to receive larger amounts of trade credit (Petersen \& Rajan, 1997; Kihanga et al., 2010; GarcíaTeruel \& Martínez-Solano, 2010), which may be attributed to their perceived high credit quality. In trade credit supply however, the results are mixed (e.g., GarcíaTeruel \& Martínez-Solano, 2010; Petersen \& Rajan, 1997).

\section{Trade Credit Discounts, Discount Period and High Interest Controversy}

Only two-part terms have discount provisions. The most widely used two-part term in the business world is $2 / 10$ net 30 . However, credit terms and discount offer differ across countries (Ferrando \& Mulier, 2013) and industrial sector (Klapper et al., 2012). Klapper et al. (2012) found that only $13 \%$ of trade credit contracts offer early payment discount, with suppliers that retail in hard goods more likely to offer discounts. Furthermore, they found that smaller firms offer discounts to customers that carry market power, implying price reduction for these firms. Danielson and Scott (2000) found that discounts are offered in less than $50 \%$ of purchases by firms, suggesting a supplier can use a combination of discount and straight terms for a customer in one transaction. Ellingsen et al. (2016) observe no early payment discounts in Sweden while Fabbri and Klapper (2016) report that about 20\% of firms in China offer early payment discounts. Ng et al. (1999) found net terms among agro-food firms producing perishable products, while both terms are found among 
firms supplying less perishable food products. Two-part credit terms are common among suppliers with established reputation for product quality (ibid).

The actual interest charges on trade credit are largely unknown. The widely held view in the literature is that the implicit interest charged on trade credit is higher than bank credit, making trade credit an expensive credit and secondary to bank credit (Petersen \& Rajan, 1997; Lin \& Chou, 2015, Cuevas et al., 1993; Ferris, 1981; Smith, 1987; Ng et al., 1999; Wilson \& Summers, 2002). The discount rate usually serves as the basis for computing the implicit interest rates and then comparison is made with bank interest rates. In the literature, the implicit yearly interest rate is compounded in the range of $18.5 \%-45 \%$. Specifically, given a $2 / 10$ net 30 terms, the $10^{\text {th }}$ day is considered a grace period and, if payment is made by that date, the credit is interest free. Beyond the $10^{\text {th }}$ day, the buyer is effectively borrowing for the next 20 days at an interest rate of $2 \%$, which is compounded to yearly implicit interest rate of about $43.9 \%$ ( $\mathrm{Ng}$ et al., 1999). ${ }^{18}$ With empirical data, many studies have challenged the notion that trade credit is more expensive than bank credit (e.g., Marrotta, 2005; Fabbri \& Klapper, 2008; Burkart \& Ellingsen; 2004; Chludek, 2011; Klapper et al., 2012). Klapper et al. (2012) show that trade credit is a cheaper short-term financing source. In their compar.

ative estimation of implicit cost of trade credit and interest cost of bank credit, Fabbri and Klapper (2008) found trade credit to be a cheaper source of working capital. Chludek (2011) estimates the average trade credit interest rates to be between 4-6\%, comparable to rates offered by alternative financing sources. Cheng and Pike (2003) show that firm managers in the UK consider trade credit as interest free loans with cash discounts offers and lengthening of credit period being equivalent to price reductions relative to list prices when firms take advantage of the discounts. Ellingsen et al. (2016) examined longitudinal data of 52 million trade credit contracts for some 51 firms over a period of 9 years and show that trade credit is a cheaper source of credit and is prioritised by firms over other sources of financing. If discounts are price reductions to elicit early payment, it thus calls to question the use of discount rates as basis for computing implicit interest on trade credit. What will be the basis for computing implicit interest on trade credit if net terms are offered? In general, the extensive use of trade credit in business transactions calls to question the notion of 'expensive trade credit.' Aside the financing motive, charging interest on trade credit will be counter-intuitive if the motives for trade credit are transactional and commercial.

18 Formula from Ng et al. (1999): Inplicit interest rate $=\left\{\left(\frac{100}{100-\text { Discount rate }}\right)^{360 / \text { discount period }}-1\right\}$ 


\section{Trade Credit Period}

In general, 30-day credit periods are commonly reported in the literature (Klapper et al., 2012; Ferrando \& Mulier, 2013; Ellingsen et al., 2016). Nevertheless, there are wider variations by country, industry and transaction. Credit terms less than 30 days and greater than 30 days have been reported (Ng et al., 1999; Fafchamps et al., 1995; Fabbri \& Klapper, 2016). While Ng et al. (1999) and Costello (2013) found trade credit terms to be relatively standard within industries, however, for industries that are highly heterogeneous such as the food industry, variations may be significant. Deloof and Jegers (1996) and Long et al. (1993) found about 62 days of payables outstanding among firms. Ferrando and Mulier (2013) found average maturity period of payables of 30 days in Germany and Finland and higher period (over 50 days) in Spain, Italy and Portugal; they found an even higher period in trade receivables (over 100 days). Cheng and Pike (2003) found days of payables ranging from 5-60 days, with 34 days on average. Huyghebaert (2006) reports an average of 84 days of payable outstanding among Belgium industrial firms while Fabbri and Klapper (2016) found payment period ranging from 1-6 months in China. Costello (2013) noted an average trade credit period of 47.6 days, $15 \%$ of contracts increase the amount of trade credit relative to the previous contract, and $18 \%$ percent of contracts increase the duration of trade credit relative to the previous contract. This shows the importance of building trust and reputation in trade credit relationships.

Shorter credit periods have been shown to be associated with soft or non-complex goods (Klapper et al., 2012; Ng et al., 1999). For instance, Costello (2013) reports longer net days for more complex products ranging from 8 days for perishable food products to 90 days for instruments. The rate of goods turnover (production cycle) is inversely related to credit period (Long et al., 1993; García-Teruel \& MartínezSolano, 2010; Deloof \& Jegers, 1996). Long et al. (1993) attribute this to quality verification motive as more time is required for customers to verify the quality of difficult-to-observe-quality products before making payment. Firms producing soft products (easy-to-observe-quality-goods) will offer shorter credit periods. The duration of credit increases with firm size (Fafchamps et al., 1995; Ellingsen et al., 2016) and international customers (Cuevas et al., 1993) and customers with market power (Ellingsen et al., 2016; Fabbri \& Klapper, 2016). Many of the reported average trade credit periods are days of credit outstanding and not necessarily, what the initial contracts may stipulate. Overdue payments are reportedly common in trade credit relationships (Fafchamps et al., 1995; Ng et al., 1999; Fabbri \& Klapper, 2016; Ellingsen et al., 2016; Cuevas et al., 1993). 


\section{THEORIES OF TRADE CREDIT: APPLICATIONS AND LIMITATIONS}

The theories of trade credit are centred on various motives driving trade credit activity. They are presented in Table 1, grouped into three broad categories: financing, operation/transaction and commercial theories.

Table 1: Theories of trade credit

\begin{tabular}{|c|c|c|}
\hline Broad Category & Specific Theory & Seminal Papers \\
\hline Financing theories & $\begin{array}{l}\text { Financing advantage theory- } \\
\text { information, liquidation, liquidity } \\
\text { and financial distress, monetary } \\
\text { policy }\end{array}$ & $\begin{array}{l}\text { Schwartz (1974); Emery (1984); } \\
\text { Melzer (1960) }\end{array}$ \\
\hline $\begin{array}{l}\text { Transaction/operational } \\
\text { theory }\end{array}$ & Transaction cost theory & Ferris (1981); Emery (1984) \\
\hline \multirow[t]{5}{*}{ Commercial theories } & $\begin{array}{l}\text { Marketing, market power and } \\
\text { competition theories }\end{array}$ & $\begin{array}{l}\text { Nadiri (1969); } \\
\text { Wilson \& Summers (2002) }\end{array}$ \\
\hline & Price discrimination theory & Brennan et al. (1988) \\
\hline & $\begin{array}{l}\text { Quality guarantee/verification } \\
\text { theory }\end{array}$ & Smith (1987); Long et al. (1993) \\
\hline & Long-term relationship & $\begin{array}{l}\text { Summers \& Wilson (2000); } \\
\text { Long et al. (1993) }\end{array}$ \\
\hline & Tax theory & $\begin{array}{l}\text { Brick \& Fung (1984); } \\
\text { Brennan et al. (1988) }\end{array}$ \\
\hline
\end{tabular}

\section{Financing Theories}

These are the first theories of trade credit that emerged. Trade credit arises from financial market imperfections (Emery, 1984). There are versions of the financing theory including the information advantage theory, liquidity (and financial distress) theory, asset liquidation theory and monetary policy effects. The information advantage theory posits that suppliers have information advantage over traditional financial intermediaries and are therefore able to engage in financial intermediation at lower transaction costs. Suppliers gain information about their clientele as a by-product of their close proximity and regular interaction (Petersen \& Rajan, 1997), making it easier and cheaper for them to establish the creditworthiness of their clientele ex ante and monitor and enforce credit contracts ex post (Emery, 1984). In cases of default, suppliers are better able to establish whether the default 
is intentional or unintentional, to inform appropriate actions ( $\mathrm{Ng}$ et al., 1999). In addition, suppliers deal with customers that are relatively homogenous, making it easier and cheaper to collect information as oppose to a heterogeneous clientele portfolio of banks. The asset liquidation theory dictates that firms have advantage over traditional financial intermediaries in seizing and liquidating the assets of defaulting borrowers at lower transaction cost (Emery, 1984; Peterson \& Rajan, 1997). This is because suppliers and buyers operate within the same or similar value chains (Emery, 1984).

The liquidity theory focuses on suppliers with excess liquidity investing in trade credit to generate returns. According to Schwartz (1974), firms with easier and cheaper access to credit in the capital markets may have the incentive to borrow and in turn use the funds to finance the purchases of customers who may be credit rationed. This is referred to as 're-distributional' role of trade credit (Meltzer, 1960). The optimal level of trade credit is attained when the marginal revenue of supplying trade credit is equal to the marginal cost (Emery, 1984). The effect of changes in monetary policy on trade credit supply and demand is at the macro-level. In a tight monetary policy regime, interest rates are driven up and credit rationing increases, constraining the ability of firms to access credit from capital markets. The creditrationed firms will thus tend to depend more on their suppliers to finance their purchases. Therefore, trade credit use will increase under tight monetary policy regime and vice versa (Meltzer, 1960; Schwartz, 1974). This has been confirmed by Meltzer (1960) and Mateut et al. (2006). Periods of economic downtowns and financial crisis also increase trade credit activity (Lin \& Chou, 2015).

The financing theories has several limitations. The financing theory cannot adequately explain prepayment/ advanced payment form of trade credit. The implicit assumption that trade credit and bank credit are substitutes is questioned by many recent studies that have found a complementary relationship (Carvalho \& Schiozer, 2015; Vaidya, 2011; Fisman \& Raturi, 2004). Additionally, the assumption that bank credit is superior to trade credit is seriously challenged with recent empirical evidence (e.g., Marotta, 2005; Ellington et al., 2016). In many studies, younger and smaller firms that should be credit-rationed according to the financing theory are found to supply more trade credit (Kihanga et al., 2010; Long et al., 1993; Fabbri \& Klapper, 2008), thus reducing the explanatory power of the financing theory. The liquidation theory is inapplicable in transactions involving services. The financing motive may be inapplicable to trade credit with shorter credit periods (Schwartz, 1974). In sum, though the financing theory provides relevant explanation on the use of trade credit, it is inadequate in comprehensively 
explaining all aspects of trade credit activity, implying non-financial theories may also be relevant. Empirically, the results are mixed: some studies have found support ( Lin \& Chou, 2015; Huyghebaert, 2006; García-Teruel \& Martínez-Solano, 2010; Peterson \& Rajan, 1997; Carvalho \& Schiozer, 2015; Costello, 2013; Deloof \& Jegers, 1996), partial support ( Danielson \& Scott, 2000) and no support (Alarcón, 2011; Ng et al., 1999; Giannetti et al., 2011; Marotta, 2005; Ellingsen et al., 2016).

\section{Transaction (or Operational) Theory}

Contrary to the neoclassical assumption of the absence of transaction costs in economic exchanges, there are ex ante and ex post transaction costs (Williamson, 1985) that should be considered in making economic decisions. Ferris (1981), Schwartz (1974) and Emery (1984) put forth the transaction theory, however, Schwartz (1974) and Emery (1984) later abandoned the transaction theory in favour of financing theory in same papers. According to the transaction cost theory, using trade credit can improve operational efficiency and economise on transaction costs for all transacting parties (Schwartz, 1974; Ferris, 1981). Joint economisation of transaction costs of exchanges can be achieved through 'separation of exchange of goods from the exchange of money' (Ferris, 1981; p. 244). By granting trade credit, both transacting parties can economise on transaction costs by allowing payments to be accumulated and paid periodically. In so doing, both parties can avoid the number of trips they make to the bank and reduce other transaction costs such as frequent transportation costs and bank charges (Schwartz, 1974). The level of transaction costs savings that can be realised is dependent on transaction frequency, uncertainty and the degree to which investments are transaction specific [see Williamson (1979) characterization of transactions]. There can be cost savings by employing trade credit where transactions are frequent (Petersen \& Rajan, 1997). For goods that are highly specific, prepayment or advance payment type of trade credit may be crucial in managing risks (Cuevas et al., 1993).

Transaction costs increase when economic exchanges are characterised by supply and demand uncertainties (Ferris, 1981). Firms can offer trade credit to customers who buy goods in periods of low demand, thus reducing storage cost by avoiding excessive inventories while the buyers will have adequate inventories to smoothen production (Petersen \& Rajan, 1997; García-Teruel \& Martínez-Solano, 2010). Similarly, generous terms of trade credit can be offered to encourage purchases when there is deficit in demand (Emery, 1984). Offering trade credit can increase the volume of trade per transaction, which in turn may lead to reduction in costs such as transportation costs (Kihanga et al., 2010). According to Schwartz (1974), 
the explanatory power of transaction theory diminishes when it comes to observed variations in credit periods between firms and in different industries. Also, the response of trade credit to changes in monetary policy cannot be explained by transaction motive. Another limitation as highlighted by Ferris (1981) is that the relevance of transaction motive is limited to short period credit. Studies supporting the theory include Ferrando and Mulier (2013), Huyghebaert (2006), Ng et al. (1999), Wilson and Summers (2002), Cheng and Pike (2003), Elliehausen and Wolken (1993) and Vaidya (2011). García-Teruel and Martínez-Solano (2010) found no support for the theory.

\section{Marketing, Market Power and Competition Theories}

Trade credit can be deployed by firms as marketing or sales promotion device to drive sales (Nadiri, 1969; Wilner, 2000). Nadiri (1969) argue that trade credit and advertisement produce similar effects as both are investments that yield expected benefits to a firm over time. Therefore, the cost of supplying trade credit is synonymous with advertising expense and should be treated as such (ibid). Trade credit can shift the position of the demand curve for firms' products through market expansion. Especially for new entrants in a market or for newly introduced products, trade credit can serve as an important marketing tool to gain market share (Wilson \& Summers, 2002). Trade credit and credit terms can be varied to stimulate demand; a firm can extend more trade credit on favourable terms during periods of low demand and tighten credit terms during periods of high demand (Emery, 1984; Cheng \& Pike, 2003). Bhattacharya (2008) relates the use of trade credit as a marketing device to the 'push' strategy of marketing. Suppliers can push their products into distribution channels using trade credit as incentive. Offering trade credit may enable a firm to differentiate its products from those of its competitors, building competitive advantage in the process (Cheng \& Pike, 2003).

The effectiveness of trade credit as marketing tool is dependent on the degree of market competition. The use of trade credit is expected to be high in markets characterised by high competition. As customer switching between suppliers may be pronounced in competitive markets, offering trade credit may help gain and/ or retain customers (Cheng \& Pike, 2003; Fisman \& Raturi, 2004; Van Horen, 2005). Hermes et al. (2012) found that extension of trade credit prevents customer switching in Tanzania. As confirmed by Fisman and Raturi (2004) and Van Horen (2005), firms operating in less competitive markets, such as monopolistic markets, will supply less trade credit. The supply of trade credit will be particularly high among small and young firms as a competitiveness strategy (Long et al., 1993; 
Cheng \& Pike, 2003). However, large firms may also seek to establish and maintain market power by offering more trade credit (Brennan et al., 1988). In this way, trade credit can reduce market competition and create entry barriers for new firms. Where a customer commands more market power than a supplier, trade credit supply will be on the terms of the customer. Customers that carry market power may force suppliers to extend trade credit using threat of switching (Van Horen, 2005; Fabbri \& Klapper, 2008). Customers with market power are also likely to be offered favourable terms of trade credit (Klapper et al., 2012; Ellingsen et al., 2016). Firms that are in financial distress may still be compelled to sell on credit in order to maintain powerful customers. This theory has been largely supported (Nadiri, 1969, García-Teruel \& Martínez-Solano, 2010, Fisman \& Raturi, 2004, Cuevas et al., 1993, Van Horen, 2005, Cheng \& Pike, 2003; Fabbri \& Klapper, 2016). However, Kihanga et al. (2010) and Costello (2013) found no empirical support.

\section{Long-Term Relationship Theory}

Trade credit may be employed to attract and build long-term relationships with customers, an investment that is expected to yield a stream of benefits over time (Nadiri, 1969; Wilner, 2000; Wilson \& Summers, 2002). Customer switching is a common phenomenon; Reichheld and Sasser (1990) state yearly customer defection rates of about $15-20 \%$. According to Cheng and Pike (2003), offering trade credit may not only enable a firm to attract new customers, it can also be used to retain and develop a stable customer base for a firm's products. Relationship building is especially important for newly established firms entering the market (Wilson \& Summers, 2002) and in competitive industries where customer switching is prevalent (Van Horen, 2005; Alarcón, 2011). A supplier extending trade credit may signal to customers that the supplier intends to develop and maintain long-term business relationships (Smith, 1987; Cheng \& Pike, 2003). A firm may offer trade credit to distressed firms, despite the high risk, as a way of supporting their survival because they have a stake in their long-term survival (Wilner, 2000). Conversely, credit constrained firms may extend trade credit as a way of retaining customers and increasing sales (Brennan et al., 1998; Van Horen, 2005; Fabbri \& Klapper, 2008). Moreover, trade credit terms can be varied to reward loyal customers especially when they are in distress (Cheng \& Pike, 2003). This theory has been supported by Cheng and Pike (2003), Cuevas et al. (1993) and Hermes et al. (2012). 


\section{Quality Guarantee (Verification or Assurance) Theory}

This theory has its foundations in information economics and agency theory. Information asymmetry between sellers and buyers on quality of goods constrain the demand for goods by the latter (Smith, 1987). The inability of buyers to determine the quality of products ex ante affects their purchasing decisions as buyers will want to convince themselves they are not buying 'lemons' (see Akerlof, 1970). The quality guarantee theory stipulates that credit sales may serve as implicit guarantee for goods quality. This will allow time for buyers to verify the quality of goods before making payment (Smith, 1987; Long et al., 1993; Fafchamps, et al., 1995). Trade credit in this sense consists of deferred payment terms extended to buyers until they verify product quality (Long et al., 1993). In a study of US, UK and Australian firms, Pike et al. (2005) found that firms use trade credit terms to reduce information asymmetries. When the volume of purchases is high, it is very difficult to conduct on-the-spot verification, allowing firms time to verify the quality and quantity of goods supplied can facilitate trade (Fafchamps et al., 1995). The length of time allowed for verification is directly related to the volume and degree of complexity of goods involved in exchanges. Longer periods are required if the products being offered are complex and the quality is not obvious (Long et al., 1993; Deloof \& Jegers, 1996). For this reason, Long et al. (1993) argue that agro-food products require less time for verification in that they are highly perishable and easy to observe their quality. Furthermore, Long et al. (1993) and Deloof and Jegers (1996) argue that firms with longer production cycles will supply more trade credit to customers. While Long et al. (1993) found empirical support among American firms, Deloof and Jegers (1996) found no relationship among Belgium firms.

Offering trade credit also convey signal about the quality of goods (see Smith, 1987; Long et al., 1993). Where buyers are unable to distinguish between product types, only high-quality suppliers will offer trade credit (Long et al., 1993). A firm supplying 'lemons' will tend to demand cash payment. Conditioned on information asymmetry, Vaidya (2011) argue that firms offering large discounts on goods to elicit early payment should signal low quality goods. The theory has very limited explanatory power for well-established firms or products. Thus, the quality verification theory cannot survive subsequent trade credit activity between a firm and its customers after initial periods of transaction. Additionally, in markets where the products are not uniquely identifiable, the quality verification motive has limited explanatory power (Long et al., 1993). In general, under perfect competition, the quality verification motive cannot explain the existence of trade credit as information asymmetries between transacting parties will not exist. While Long et al. (1993) found empirical support, Deloof and Jegers (1996) and Ng et al. (1999) found partial support, and Costello (2013) found no support. 


\section{Price Discrimination Theory}

Firms may employ various strategies to price discriminate indirectly outside the permissible boundaries. The price discrimination theory posits that firms may price discriminate indirectly using trade credit (see Petersen \& Rajan, 1997; Brennen et al., 1988). This generally works in favor of low credit quality or risky customers. If both high - and low-quality customers are granted the same trade credit terms, the effective price of the goods is reduced for the low-quality customers, enabling them to express their demand (Petersen \& Rajan, 1997). Ceteris Paribus, prices should be risk-adjusted for low-quality customers. However, Ng et al. (1999) argue that the gains from extending trade credit to risky customers may be higher if they are the ones that constitute the price elastic segment of the market. GarcíaTeruel and Martínez-Solano (2010) argue that prolonging the period of credit payment or offering huge cash discounts to elicit prompt payment is a form of price discrimination as the same goods will in effect be sold at different prices to different buyers based on their response to the credit terms. Offering favorable trade credit terms to distressed firms with the aim of helping them to survive (e.g., Petersen \& Rajan, 1997) constitute price discrimination. Also, imperfections in the product market may provide grounds for price discrimination as customers may have different reservation prices (Vaidya, 2011). Firms with market power can enhance their returns through price discrimination using trade credit (Cheng \& Pike, 2003). Empirically, García-Teruel and Martínez-Solano (2010), Giannetti et al. (2011), Vaidya (2011), Cheng and Pike (2003), Pike et al. (2005), and Ng et al. (1999) found support for price discrimination theory. Kihanga et al. (2010) found only partial support while Alarcón (2011) and Peterson and Rajan (1997) found no support.

\section{Tax Theory}

The tax theory of trade credit is built generally on two arguments: (1) deferment of tax liabilities through trade credit supply, and (2) capital relocation between high and low tax jurisdictions using trade credit as vehicle. Brick and Fung (1984) showed that the accounting system affects the timing of tax liability of suppliers and tax deductibility of buyers and hence their cashflows. Firms can supply trade credit as means of deferring their tax liabilities and enhancing their cashflow under high tax regimes (Brick \& Fung, 1984; Mian \& Smith; 1992; Brennan et al., 1988). However, the effect of trade credit on taxation is dependent on the accounting system in practice (Desai et al., 2016; Brick \& Fung, 1984; Emery, 1984). Under cash accounting system, the supplier does not have tax liability until payment for goods supplied on credit terms is received and the buyer does not receive immediate tax 
deduction until payment for goods is made. With this, selling on credit may enable suppliers to avoid immediate tax payment, thus improving their cashflows. Under accrual accounting, however, when trade credit is offered, tax liabilities are due at the time of sale even though cash has not been received and the buyer also receives tax deduction even though payment is yet to be made (Desai et al., 2016; Brick \& Fung, 1984).

Trade credit may be used to reallocate capital from low tax to high tax jurisdictions. Desai et al. (2016) argue that high tax rates drive up the cost of capital, resulting in low investment levels and high pre-tax returns on invested capital. Since pretax returns on invested capital are higher in high tax jurisdictions, extending trade credit from low tax jurisdictions to affiliates in high tax jurisdictions (capital transfer) brings about mutual benefits to the parties (ibid). The limitations are that, the theory is effective only under cash accounting system and where the payment period is longer to permit the needed investment. Desai et al. (2016) and Long et al. (1993) found empirical support for tax theory in their respective studies.

\section{Towards a Comprehensive Theory of Trade credit}

Many studies employ proxy variables to test the trade credit theories and for the same theory, it is common to observe different proxy variables deployed. This limits the comparability of findings. For many of the studies, it is often the case that more than one theory is confirmed. This suggests that firms have different motives for engaging in trade credit activity at the same and different times, and with different trading partners. Thus, motives for trade credit may vary cross-sectionally and inter-temporally. There is also considerable overlap among the theories (see also Long et al., 1993, Cheng \& Pike, 2003). Even though a supplier may be offering trade credit with a specific motive (primary motive) in mind, other motives may come into play as by-products of the primary motive. The interrelated nature of the theories is confirmed by the fact that researchers tend to infer more than one theory (or motive) from a single variable (e.g., Long et al., 1993; Petersen \& Rajan, 1997; Alarcón, 2011). These interrelationships should serve to guide methodological approaches to testing these theories. Also, in efforts to develop a comprehensive theory of trade credit, these interrelationships should be recognised and should inform the approach(es). Moreover, the existing theories appear to be centred, generally, on transaction cost and information asymmetry reduction and should thus be a focal point in efforts towards comprehensive theory development in the field. 


\section{CONCLUSION AND IMPLICATIONS FOR POLICY AND FUTURE RESEARCH}

As shown in the paper, the incidence and level of supply and demand for trade credit are high. This should warrant some policy attention, particularly regulatory attention by governments. Some regulation is especially important as trade credit has limitations. Suppliers of trade credit face the risk of bad debts if enforcement mechanisms are ineffective. Also, payment delays, as commonly reported in the literature, can disrupt firms cashflows, delay planned investments and cause firms to lose value. Offering discounts for early payment represent price reductions, which can affect firms profits unless the prices of the goods are adjusted for interest. For buyers, payment delays can cause them to lose key suppliers. Additionally, buyers may face high prices of goods and hence reduced profitability if goods prices are adjusted for interest and provided the interests on trade credit are higher than interests on bank credits. For reverse trade credit particularly, buyers run the risks of delayed supply of goods, which may disrupt planned operations or risks losing their prepayments completely if suppliers fail to perform the contract and enforcement mechanisms are ineffective. In general, managing trade credit comes with transaction costs for suppliers and receivers.

Trade credit contracts are not particularly complex, and factors such as shortness of credit period, frequent transactions, close proximity and interaction between suppliers and customers, and effective informal enforcement mechanisms may account for the observed nature of trade credit contracts. There are variations in trade credit usage, terms, and maturity periods across countries and industries, and even within industries. Future research should focus on specific industries as industry level studies are rare. The wide use of trade credit around the world suggests that trade credit is cheaper relative to other sources of financing. Arguments for costly trade credit are grounded on aspects of the financing theory and are not sustained by the empirical evidence. Charging interest on trade credit cannot be supported by the non-financial theories of trade credit. The use of trade credit in inter-firm trade is a multidimensional phenomenon driven by varied yet interconnected motives. These inter-relationships should serve to guide methodological approaches to testing these theories. Existing theories appear to be generally centred on transaction cost and information asymmetry reduction, which present an opportunity for comprehensive theory development in the field. Most of the theories have received considerable empirical support in both developed and developing countries. 


\section{REFERENCES}

Akerlof, G. A. (1970). The market for "lemons": Quality uncertainty and the market mechanism. The Quarterly Journal of Economics, 84(3), 488-500.

Alarcón, L. S. (2011). The trade credit in the Spanish agrofood industry. Mediterranean Journal of Economics, Agriculture and Environment, 10(2), 51-57.

Boissay, F. \& Gropp, R. (2007). Trade Credit Defaults and Liquidity Provision by Firms. European Central Bank Working Paper No.753. https://www.ecb.europa.eu/ pub/pdf/scpwps/ecbwp753.pdf

Bhattacharya, H. (2008). Theories of Trade Credit: Limitations and Applications. https:// papers.ssrn.com/sol3/papers.cfm?abstract_id=1286443

Brennan, M., Maksimovic, V. \& Zechner, J. (1988). Vendor financing. Journal of Finance, 43, 1127-1141.

Brick, I. E. \& Fung, W. K. (1984). The effect of taxes on the trade credit decision. Financial Management, 13(2), 24-30.

Burkart, M. \& Ellingsen, T. (2004). In-kind finance: A theory of trade credit. The American Economic Review, 94(3), 569-590. 10.1257/ooo2828041464579.

Carvalho, C. J. D. \& Schiozer, R. F. (2015). Determinants of supply and demand for trade credit by micro, small and medium-sized enterprises. Revista Contabilidade and Finanças, 26(68), 208-222.

Cheng, N. S. \& Pike, R. (2003). The trade credit decision: evidence of UK firms. Managerial and Decision Economics, 24(6-7), 419-438.

Chludek, A. K. (2011). A note on the price of trade credit. Managerial Finance, 37(6), 565-574.

Costello, A. (2013). The determinants and economic consequences of trade credit policy. http://leeds-faculty.colorado.edu/zeyun/workshop13-14 files/ CostelloTC(October2013).pdf.

Crocker, K. J. \& Reynolds, K. J. (1993). The efficiency of incomplete contracts: An empirical analysis of air force engine procurement. The RAND Journal of Economics, 24(1), 126-146.

Cuñat, V. \& Garcia-Appendini, E. (2012). Trade credit and its role in entrepreneurial finance. In Cumming, D. (eds.), Oxford Handbook of Entrepreneurial Finance (526-557). New York: Oxford University Press. https://dx.doi.org/10.1093/ oxfordhb/9780195391244.001.0001. 
Danielson, M. G. \& Scott, J. A. (2000). Additional Evidence on the Use of Trade Credit by Small Firms: The Role of Trade Credit Discounts. http://dx.doi.org/10.2139/ ssrn.23626o.

Daripa, A. \& Nilsen, J. (2011). Ensuring sales: A theory of inter-firm credit. American Economic Journal: Microeconomics, 3(1), 245-279.

Dary, S. K. \& James, H. S. (2019). Does Investment in Trade Credit Matter for Profitability? Evidence from Publicly Listed Agro-Food Firms. Research in International Business and Finance, 47, 237-250.

Dary, S. K. \& James, H. S. (2018). Trade credit supply in African agro-food manufacturing industry: determinants and motives. Agricultural Finance Review, 78(3), 312-329.

Deloof, M., \& Jegers, M. (1996). Trade credit, product quality, and intragroup trade: some European evidence. Financial Management, 25(3), 33-43.

Desai, M. A., Foley, C. F., \& Hines Jr., J. R. (2016). Trade credit and taxes. Review of Economics and Statistics, 98(1), 132-139.

Dyer, J. H. (1997). Effective interfirm collaboration: how firms minimise transaction costs and maximise transaction value. Strategic Management Journal, 18(7), $535-556$.

Elliehausen, G. \& Wolken, J. (1993). An empirical investigation into motives for demand for trade credit. Federal Reserve Board Staff Study, 165. https://www.federalreserve.gov/pubs/staffstudies/1990-99/ss165.pdf.

Emery, G. W. (1984). A pure financial explanation for trade credit. Journal of Financial and Quantitative Analysis, 19(3), 271-285.

Fabbri, D. \& Klapper, L. F. (2016). Bargaining power and trade credit. Journal of Corporate Finance, 41, 66-80.

Fabbri, D. \& Klapper, L. (2008). Trade credit supply, market power and the matching of trade credit terms. Policy Research Working Paper, 4754. World Bank, Washington DC.

Fafchamps, M., Pender, J., \& Robinson, E. (1995). Enterprise finance in Zimbabwe. RPED Case Study Series. World Bank, Washington DC. http://www-leland.stanford. edu/ fafchamp/zimba.pdf.

Ferrando, A. \& Mulier, K. (2013). Do firms use the trade credit channel to manage growth? Journal of Banking \& Finance, 37(8), 3035-3046.

Ferris, J. S. (1981). A transactions theory of trade credit use. The Quarterly Journal of Economics, 96(2), 243-270. 
Fisman, R. \& Raturi, M. (2004). Does competition encourage credit provision? Evidence from African trade credit relationships. Review of Economics and Statistics, 86(1), 345-352.

García-Teruel, P. J. \& Martínez-Solano, P. M. (2010). Determinants of trade credit: a comparative study of European SMEs. International Small Business Journal, 28(3), 215-233.

Giannetti, M., Burkart, M. \& Ellingsen, T. (2011). What you sell is what you lend? Explaining trade credit contracts. Review of Financial Studies, 24(4), 1261-1298.

Hermes, N., Kihanga, E., Lensink, R. \& Lutz, C. (2012). The impact of trade credit on customer switching behaviour: Evidence from the Tanzanian rice market. Journal of Development Studies, 48(3), 363-376.

Huyghebaert, N. (2006). On the determinants and dynamics of trade credit use: Empirical evidence from business start-ups. Journal of Business Finance and Accounting, 33(1-2), 305-328.

Kihanga, E., Lensink, R., Lutz, C. \& Hermes, N. (2010). Determinants of trade credit demand and supply in the Tanzanian rice market: A Structural Modelling Approach. http://dx.doi.org/10.2139/ssrn.1674842.

Klapper, L., Laeven, L. \& Rajan, R. (2012). Trade credit contracts. Review of Financial Studies, 25(3), 838-867.

Lin, T. T. \& Chou, J. H. (2015). Trade credit and bank loan: Evidence from Chinese firms. International Review of Economics \& Finance, 36, 17-29.

Long, M. S., Malitz, I. B. \& Ravid, A. (1993). Trade credit, quality guarantees, and product marketability. Financial Management, 22(4), 117-127.

LR Bookkeeping (2014, September 19). Take advantage of purchase discounts! [weblog post]. http://bookkeeper-help.blogspot.com/.

Marotta, G. (2005). When do trade credit discounts matter? Evidence from Italian firm-level data. Applied Economics, 37(4), 403-416.

Mateut, S. (2014). Reverse trade credit or default risk? Explaining the use of prepayments by firms. Journal of Corporate Finance, 29, 303-326.

Mateut, S., Bougheas, S. \& Mizen, P. (2006). Trade credit, bank lending and monetary policy transmission. European Economic Review, 50(3), 603-629.

Meltzer, A. H. (1960). Mercantile credit, monetary policy, and size of firms. The Review of Economics and Statistics, 42(4), 429-437. 
Mian, S. L. \& Smith, C. W. (1992). Accounts receivable management policy: Theory and evidence. The Journal of Finance, 47(1), 169-200.

Mischka, J. (2015, June 25). Invoice example-converted to pdf [weblog post]. https:// www.slideshare.net/JenniferMischka/invoice-example-converted-to-pdf

Nadiri, M. I. (1969). The determinants of trade credit in the US total manufacturing sector. Econometrica: Journal of the Econometric Society, 37(3), 408-423.

Nash, J. (1951). Non-cooperative games. Annals of Mathematics, 54(2), 286-295.

Ng, C. K., Smith, J. K. \& Smith, R. L. (1999). Evidence on the determinants of credit terms used in interfirm trade. The Journal of Finance, 54(3), 1109-1129.

Pike, R., Cheng, N. S., Cravens, K. \& Lamminmaki, D. (2005). Trade credit terms: asymmetric information and price discrimination evidence from three continents. Journal of Business Finance and Accounting, 32(5-6), 1197-1236.

Reichheld, F. F. \& Sasser, W. E. (1990). Zero Defections: Quality Comes to Services. Harvard Business Review, 68(5), 105-111.

Schwartz, R. A. (1974). An economic model of trade credit. Journal of Financial and Quantitative Analysis, 9(04), 643-657.

Smith, J. K. (1987). Trade credit and informational asymmetry. The Journal of Finance, 42(4), 863-872.

Summers, B. \& Wilson, N. (2000). Trade credit management and the decision to use factoring: An empirical study. Journal of Business Finance and Accounting, 27(1-2), 37-68.

Vaidya, R. R. (2011). The determinants of trade credit: Evidence from Indian manufacturing firms. Modern Economy, 2(5), 707-716.

Van Horen, N. (2005). Trade credit as a competitiveness tool; evidence from developing countries. Evidence from Developing Countries. https://mpra.ub.uni-muenchen. de/2792/1/MPRA_paper_2792.pdf.

Williamson, O. E. (1985). The economic institutions of capitalism. New York: The Free Press.

Williamson, O. E. (1979). Transaction-cost economics: the governance of contractual relations. Journal of Law and Economics, 22(2), 233-261.

Wilner, B. S. (2000). The exploitation of relationships in financial distress: The case of trade credit. The Journal of Finance, 55(1), 153-178. 


\section{APPENDICES}

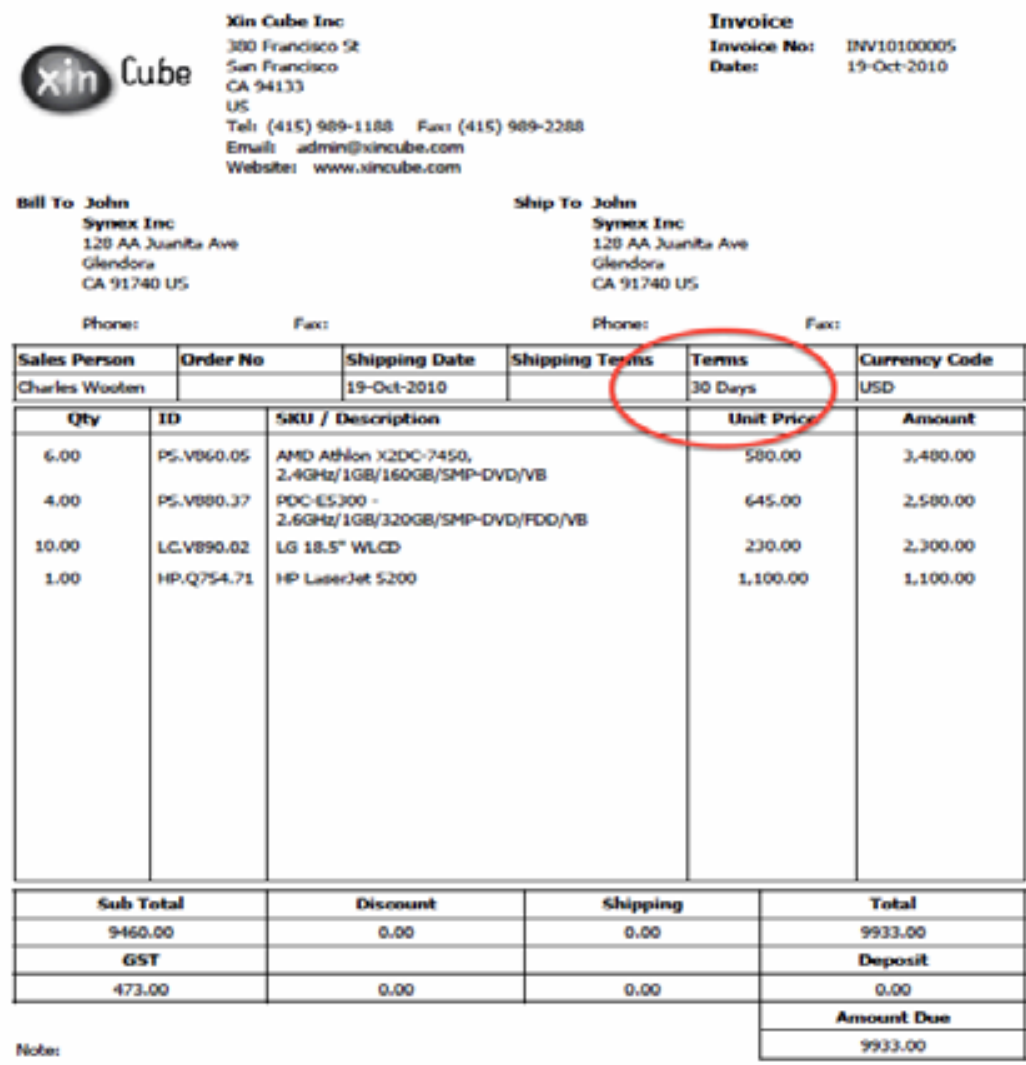

Thenlas for you busineas!

\section{Figure A1: Sample Trade Credit Contract with Net Terms}

Adopted from LR Bookkeeping (2014). 


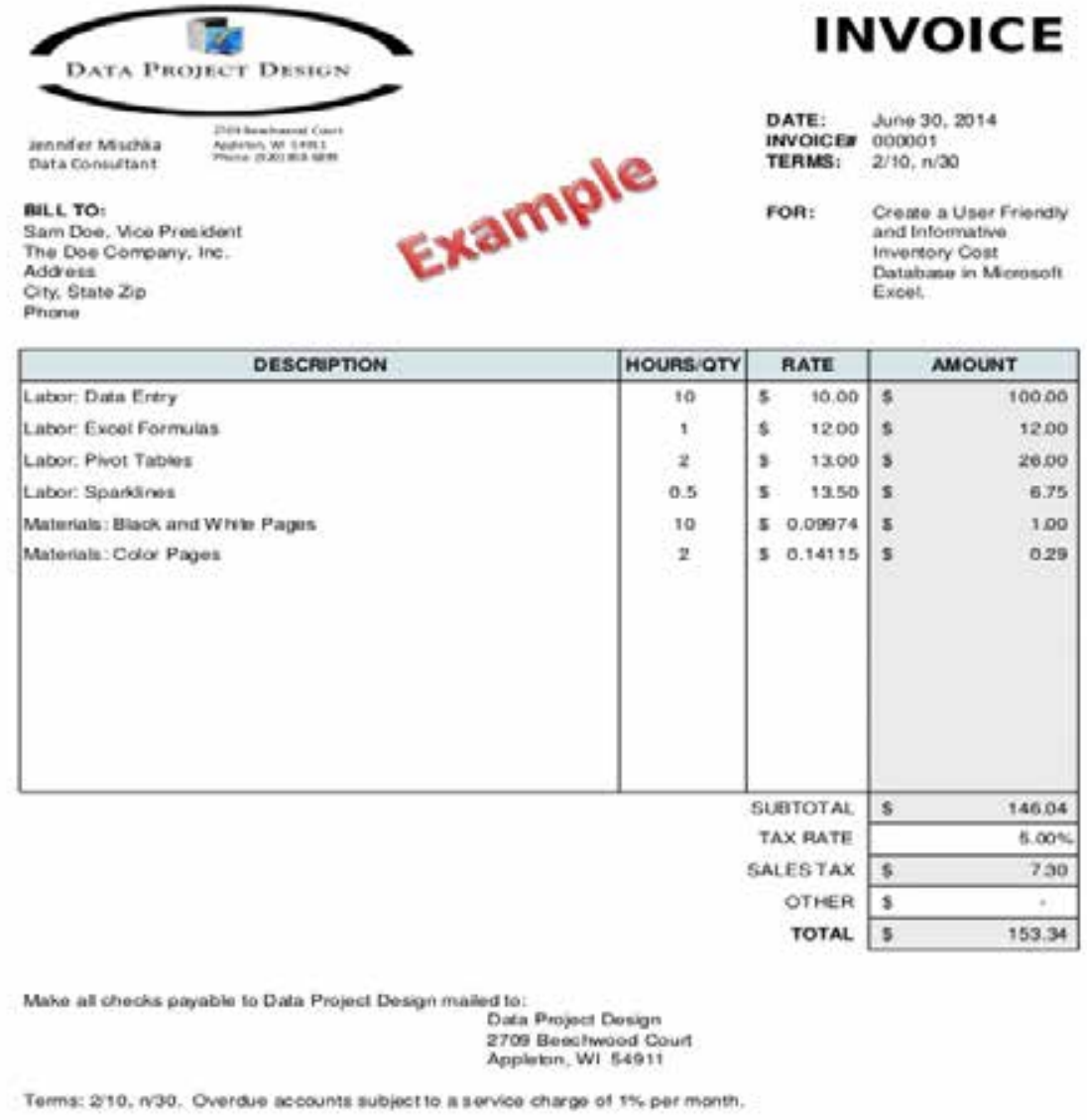

THANAK YOU FOA YOUA BUSNESS!

Figure A2: Sample Trade Credit Contract with Two-Part Terms

Adopted from Mischka (2015) 